\title{
Dynamics of Village Head Election Arrangements
}

\author{
Fence M. Wantu ${ }^{1}$ \\ Abdul Hamid Tome ${ }^{2}$ \\ ${ }^{1}$ Faculty of Law, Universitas Negeri Gorontalo, Indonesia. E-mail: fencewantu@yahoo.co.id \\ ${ }^{2}$ Faculty of Law, Universitas Negeri Gorontalo, Indonesia. E-mail: hamidtome@ung.ac.id
}

\section{Article Info}

\section{Keywords:}

Democracy; Regulation;

Election of Village Head.

\section{How to cite (APA Citation} Style):

Wantu, F. M., Tome, A. H. (2021). "Dynamics of Village Head Selection Arrangements". Jambura Law Review. JALREV 3 Special Issue: 96-116
(C) 2021 - Wantu, F. M , \& Tome, A.H. Under the license CC BY-SA 4.0

\begin{abstract}
This study aims to analyze the arrangement of village head elections from the beginning of independence until now. The method used in this study is the normative legal research method regarding primary and secondary legal materials. The legal materials obtained are then analyzed descriptively. The results showed that the arrangement of the selection of village heads has its dynamics in line with the development of the politics of the law of the state that occurs. The existing legal, political conditions influence determining the conditions for the candidates of village heads. Although it has been regulated for a long time, it turns out that all existing laws and regulations have not made arrangements related to the provisions of the supervisory mechanism and the mechanism of resolving disputes for the selection of village heads. Regulation of the Minister of Home Affairs on the Selection of Village Heads attaches supervisory duties to the regional election committee. However, it does not make arrangements for how the surveillance process should be conducted.

On the one hand, in the regulation, it is expressly mentioned the existence of supervisors in the implementation of village head elections. Nevertheless, it did not specify who the superintendent was. Similarly, the settlement of disputes for the selection of village heads is left entirely to the Regent/Mayor to do so. Granting authority to the head of the region can undermine the democratic process built by the village through the selection of village heads.
\end{abstract}




\section{Introduction}

Discussing Indonesia can not be released from the existence of the village. The village was an early entity of the birth of the country. Even at the beginning of the drafting of the state constitution, the 1945 Constitution, the nation's founders discussed the existence of the village and its position in the state government system. ${ }^{1}$ Before the country was formed, the village had been present in managing the lives of its people. When the state is associated as the largest organization in people's lives, then the village is the closest organization in fulfilling people's lives so that the recognition and respect for the existence of the village in the constitution are not unwarranted but instead has meaning as a form of state responsibility to protect the rights owned by the village.

In Sanskrit, Desa or Village comes from the word swadesi, meaning an autonomous and independent region. ${ }^{2}$ Mashuri Maschab ${ }^{3}$, defines the village in three aspects, namely: First, the sociological aspect. The sociological aspect emphasizes the village's understanding of people's lives. In the life of the villagers, the pattern of life is relatively homogeneous, living in a particular area in a strong kinship with a low level of education. The second, the economic aspect. Efforts to fulfill the needs of the village community are more dependent on the natural resources around it. In such conditions, villages with abundant natural resources will look more prosperous than villages with little availability of natural resources. Third, the political aspect. Politically, the life of the villagers is defined as a powerful organization that organizes a system of selfgovernment or autonomy. The use of villages in this political aspect is precisely the same as the construction of village understanding mentioned in Article 1 of Law No. 6

\footnotetext{
${ }^{1}$ Ni'matul Huda. (2015). "Hukum Pemerintahan Desa Dalam Konstitusi Indonesia Sejak Kemerdekaan Hingga Era Reformasi". Malang: Setara Press. p. 7-8. See also in Tome, Abdul Hamid. (2020). "Membumikan Pancasila: Upaya Pelembagaan Nilai Pancasila Dalam Kehidupan Masyarakat Desa". Jurnal Al-'Adl, 13 (1): 118-131.

${ }^{2}$ H. Ateng Syafrudin and Suprin Na'a. (2010). Republik Desa: Pergulatan Hukum Tradisional dan Hukum Modern Dalam Desain Otonomi Desa. Bandung: PT. Alumni. p. 2.

${ }^{3}$ Mashuri Maschab. (2013). "Politik Pemerintahan Desa di Indonesia”. Yogyakarta: Polgov. p. 1-2.
} 
of 2014 on Villages (Village Law) which states that a village is a group of people living in an area that has the authority to manage its government independently based on the interests of the community and traditional rights recognized by the state.

As a government organization with the right to manage and run its government independently, the village is led by a Village Head chosen through mechanisms governed by existing regulations. Based on the mandate of the Village Law, cadres are elected through a direct electoral process, which is conducted simultaneously in each region. As explained by the Village Law, efforts to conduct simultaneous elections are intended to avoid negative things in their implementation. Unfortunately, the explanation does not elaborate on what negative things are meant to be avoided from implementing the selection of village heads, according to Yasin et al. ${ }^{4}$ That is, the Draft Law on Villages never makes arrangements related to simultaneous electoral dictum. The inclusion of simultaneous election policies may be influenced by the design of simultaneous regional head elections because at the time of discussion of the bill, also discussed the Bill on Local Government and the Bill on The Election of Regional Heads.

The implementation of the elections is in line with the concept of democracy. The prerequisite of a country that declares itself as a democratic state is changing leaders periodically through the electoral process, both at the central and local levels (village). It must be recognized that village democracy can be measured from the selection process of the village head but how the people are fully involved in organizing village government. The selection of village chiefs is only a small part of efforts to strengthen the democratization of the village. So the study in this article only focuses on the dynamics of organizing the selection of village heads.

\section{Problem Statement}

Currently, the filling of village heads is regulated in such a way through the Village Law and its derivative legal products, which must be done through several stages, namely: the preparation stage, the nomination stage, the voting stage, and the determination

\footnotetext{
${ }^{4}$ Muhammad Yasin, et. al. (2015). "Anotasi Undang-Undang No. 6 Tahun 2014 tentang Desa". Jakarta: PATTIRO bekerjasama dengan The Asia Foundation. p. 146.
} 
stage. the question that arises later, how is the arrangement of elections in Indonesia from independence until now? This question is essential to ask in order to track the legal history of village head elections. So it can be known that the design of the election that occurred in the past to be juxtaposed with the current conditions.

The study of the selection of village heads has previously been conducted; one of the studies that are almost the same as this article is the research conducted by Sekar Anggun Gading Pinilih. ${ }^{5}$ The object of the study conducted by Pinilih and this article have similarities, which is the difference is the result of analysis of Law No. 6 of 2014 on Villages, primarily related to the implementation of village head elections.

\section{Method}

Normative legal research becomes an option in conducting studies on the focus of studies conducted. The research conducted is more centered on the legal aspects, with historical, conceptual, and legal approaches. The materials used in the research are the primary legal materials by making every regulation related to Village Head election a primary reference. In addition, researchers also use secondary legal materials derived from various references obtained both through books and scientific articles. The available collection of legal materials is processed and analyzed descriptively.

\section{Election of Village Head of Early Period of Independence until Old Order}

The 1945 Constitution (before the amendment) is a basic rule made by the founders of the nation that will be used to implement the state. If the construction is built in the torso of the 1945 Constitution, there will be no arrangements about the village. Article 18 , as the basis of government regulation in the region, only does the division of regional arrangements and the composition of the government. Nevertheless, the existence of the village can be traced in the Explanation of the 1945 Constitution, which mentions that the division of regions in Indonesia as stated in the article, namely large

5 Pinilih., Sekar Anggun Gading. (2016). "Laporan Penelitian Perkembangan Pegaturan, Hukum, Pemilihan Kepala di Indonesia". Semarang: FH Undip. 
and small areas, then the village is in the composition of small areas that remain recognized for its existence. ${ }^{6}$

In order to implement Article 18 of the 1945 Constitution, Law No. 1/1945 on the Position of the Regional National Committee was issued. ${ }^{7}$ According to Bagir Manan ${ }^{8}$, That this law officially revived the autonomous regional government that was erased during the Japanese occupation. This law is the first national legal product to make arrangements related to local government. The arrangements related to local government in the KKND Law are straightforward because the arrangements are general. The existence of the village itself cannot be found in every chapter. Because of the absence of provisions that specifically regulate the village in Law No. 1 of 1945, we can not find how to fill the village head.

The process of filling the village head, stipulated later in Law No. 14 of 1946 on Changes in The Procedure of Selection of Village Heads. In this law, the arrangement of elections is very minimalist, consisting of only two chapters. This law was made only by making changes to voting rights. As stated in Article 1 paragraph (2), all residents who are 18 (eighteen) years old or married have the right to vote. The birth of such construction was due to the selection of village heads at the time of the Village Head Election Ordinance (Stb. 1907 No. 212), the right to vote in elections was only given to specific groups based on their social status (in the form of wealth, positions, etc.). This means that public participation does not apply fully in the electoral process. The nature of democracy gives equal rights to everyone in government, including choosing the head of the village. According to Gajong ${ }^{9}$ that participation is the determinant of the life of

\footnotetext{
6 The use of the village as a small area can be seen in soepomo's explanation in the Grand Meeting on July 15, 1945 at the Second Session of BPUPKI, see in Saafroedin Bahar, et.al (editor). (1995). "Risalah Sidang BPUPKI-PPKI 28 Mei 1945-22 Agustus 1945". Jakarta: Sekretariat Negara RI. p. 272.

${ }^{7}$ Mahfud MD. (2010). "Politik Hukum di Indonesia”. Jakarta: PT. RajaGrafindo Persada. p. 100-101.

8 Ibid, p. 105

${ }_{9}^{9}$ Bulqiyah, Hasanul., Muadi, Sholeh., \& Tawakkal, George Towar Ikbal. (2019). "Pemilihan Kepala Desa dan Partisipasi Masyarakat Marjinal: Studi Kasus di Pulau Bawean, Indonesia". Jurnal Wacana Politik, $4(1), 68-80$.
} 
the country. Through this participation, the people use their power to be involved in the decision-making process, including deciding who will be chosen to lead it.

There are restrictions on the suffrage of the people by the Dutch in order to control whom the village head is considered to be able to "synergize" with their interests. According to Mashuri Maschab, the village chief who did not follow the Dutch wishes will be given sanctions ranging from dismissal from office even to punishment to other family members. With this condition, the Dutch are freer to exploit the resources owned by the village. ${ }^{10}$

The birth of Law No. 14 of 1946 seeks to restore the constitutional right of every citizen to be involved in the electoral process; in this context is to choose the head of the village. Although Law No. 14 of 1946 is only limited to making changes to the right to vote, as stated in Stb 1907 No. 212. However, the existence of the regulation gives equal rights for each villager in exercising his suffrage without being limited by social status. Unfortunately, this regulation does not provide arrangements for organizing elections then the process is carried out following the previous conditions.

Two years later, there was a change in the process of filling the village head. The change can be seen in Law No. 22/1948 mentions that "The Head of Village District (small town) is appointed by the Provincial Head of at least two and as many as four candidates submitted by the Village Regional People's Representative Council" (Article 18 paragraph 3). Based on this provision, there are at least 2 (two) important things that need to be underlined, namely: First, the village is qualified as a "small area/town." Law No. 22/1948 in principle regulates the implementation of local government. These laws qualifications the composition of the regions on three levels, namely: Provincial, District (Kota Besar), and Village Areas (Small Towns). In this context, the village is placed as the minor governance structure in the Indonesian system of government.

Second, the village Head /Village Head filling is done through the appointment process conducted by the Provincial Head instead of based on the selection mechanism.

10 Mashuri Maschab. (2013). “Politik Pemerintahan Desa .....”. Op.cit. p. 35-68. 
Nevertheless, before the Provincial Head made the appointment of the village head, the Village Regional People's Representative Council proposed a minimum of 2 people and a maximum of 4 village head candidates.

Such a regulatory model has not fully accommodated the democratic values that the village has. Before enacting this law, the community chose the village head, not through the appointment mechanism. Nevertheless, this law began to make arrangements for the selection process of village heads that have not been regulated in Law No. 14/1946.

In practice, Law 22/1948 could not be fully implemented because, in 1949, a transfer of power led to changes to the state constitution. In 1949, the Constitution of the United States of Indonesia was enacted, which replaced the 1945 Constitution. The RIS constitution did not last long because it received a rejection from the Indonesian nation. So in 1950, Indonesia enacted the Provisional Constitution of 1950.

At the time of the enactment of the 1950 Constitution, law 1 the year 1957 / Principal Of Local Government, as the implementation of Article 131, Article 132, and Article 133 of the Provisional Constitution 1950. The districts in the implementation of this law, divided into 3 (three) arrangements, namely level I, level II, and level III. Each of these arrangements is granted the right of autonomy in the implementation of local government and related to the establishment of the region level III, need to be careful because this area is the foundation of the organization of the state. In addition, its existence is very diverse because it is inhabited by various groups of legal people, making the process of its formation can not be done with just one form. ${ }^{11}$ Nevertheless, according to Pinilih (2016) ${ }^{12}$, Law No. 1/1957 tries to bridge the recognition of village government into the village recognized as Level III District. The course of desapraja (Level III Region) can not be realized until the end of Law No. 1/1957.13

If traced, Law No. 1/1957 has made arrangements related to the mechanism of filling the village head (if Level III area can be realized). The procedure of filling the village

\footnotetext{
11 Ni'matul Huda. (2015). “Hukum Pemerintahan Desa ....”. Op.cit. p. 127-128.

12 Pinilih, Sekar Anggun Gading. (2016). “Laporan Penelitian Perkembangan ....”. Op.cit. p. 24.

${ }^{13}$ Ni'matul Huda. (2015). “Hukum Pemerintahan Desa ....”. Op.cit. p. 128.
} 
head both through Law No. 22 of 1948 and Law No. 1 of 1957 still has similarities, namely through the mechanism of appointment by the government composition on it.

Due to political upheaval that occurred during the enactment of the 1950 Constitution. In 1959, the President issued a decree ordering that the 1945 Constitution be reenacted. The birth of this decree has given birth to a significant development of state regulation. So further arrangements are needed in dealing with it. Local government is one of the essential things that the government takes seriously to be organized. The President then issued a decree numbered 6/1959. Unfortunately in this Presidential Regulation did not make arrangements related to the selection process of the village head. Therefore, the mechanism of filling the village head still refers to Law No. 1/1957. In 1961, through Presidential Decree No. 514 of 1961, the President formed a special team given the task of conducting studies and structuring local government. The team, better known as the Soeroso Committee, gave birth to 2 (two) legal products: First, Law No. 18/1965 governing local government. This law divides regions into 3 (three) levels: level I, level II, and level III. The village that will be directed to be formed into a Level III Area should pay attention to the living conditions of the local community (including customary law and the original arrangement of its life) and the conditions of socioeconomic life development of the community.

According to this law, there is a desire to make the village into a Level III Region, so filling the village head according to this law is carried out through the appointment mechanism. The Regional Head of level carries out the process of appointing the village head. Based on the approval of the Minister of Trade. The mechanism of appointment of village heads, preceded by submissions made by the House of Representatives, concerning the candidates of the Regional Head of level III who have been eligible, a minimum of two people, and a maximum of four candidates. If the submitted candidate does not meet the requirements, then the Regional Head level. Ask the local parliament to reshuffle the other candidates to be republished. If in the second submission, still, all candidates do not meet the requirements, the appointment of the Regional Head of Tkt. III is carried out by the Minister of Home Affairs based on his/her rights (Article 14 Law Number 18 of 1965 concerning the principles of local government.). 
The office for the Regional Head of Level III is the same as the appointment made to the Regional Representative Council to reappoint the Regional Head. In the nomination of the Regional Head of level III, several requirements should be met by each candidate (Law No. 18/1965) stated that "The Regional Head who can be appointed must be an Indonesian citizen. However, in addition, the Regional Head must meet the conditions contained in the staffing regulations", must also meet the following requirements:

1. Have a spirit of unity, sincere and independent or referred to as the soul of the Proclamation of 17 August 1945 and not against the existence of the Indonesian revolution itself;

2. Agree to the 1945 Constitution, know governing power (Political Ideology), Managed Democracy (guided), Economy under control (Guided Economy and have an Indonesian Personality that agrees and participates in providing views and objectives to a country dated 17 augusts1959 and all the implementation of regulations.;

3. The right to vote is not being revoked by the rule of the court that cannot be contested;

4. Able to speak and have an experience that there is a need for work in government.

5. Know equivalent to junior high school or at least elementary school education;

6. Maximum age 30 years. ${ }^{14}$

The birth of the requirement "never hostile to the Industrial Revolution" meant that the candidate for Regional Head of Level III never had any direct involvement in helping the enemy of the state. The birth of this requirement is because even though Indonesia has been independent, there are still groups that seek to undermine the sovereignty of a country from internal and external.

Second. Law No. 19/1965 concerning Desapraja. The opinion of The Liang Gie ${ }^{15}$ aims to:

${ }^{14}$ Article 15 Law Number 18 of 1965 concerning the Principals of Local Government

15 Ni'matul Huda. (2015). “Hukum Pemerintahan Desa ....”. Op.cit. p. 133. 
1. The legislation concerning villages that are colonial in the composition of delegations of sociopolitical power and has been obsolete was replaced

2. Make national legislation that provides guarantees to a dynamic rural system and full of good performance in order to be able to complete a democratic national revolution and development paradigm; and

3. For the establishment of Level III area according to Law No. 18/1965, the need to regulate legal community unity in all regions of Indonesia to become Desapraja.

According to the legislation, Desapraja is a "legal community unity that has certain regional boundaries, has the right to take care of its motherland, choose the head of state and own property."

To become the Head of Desapraja, it must meet the requirements as stated in Law No. 19/1965 that the Head of Desapraja is the local people, provided that:

1. Minimum age of at least 25 years;

2. Have a spirit of unity, sincere and independence (Soul Proclamation 17 August 1945) and not become an enemy of the struggle for Indonesian independence itself.;

3. Agree to the 1945 Constitution, know governing power (Political Ideology), Managed Democracy (guided), Economy under control (Guided Economy and have an Indonesian Personality that agrees and participates in providing views and objectives to a country dated 17 august 1959 and all the implementation of regulations;

4. The right to vote is not being revoked by the rule of the court that cannot be contested;

5. Able to talk and have an experience that there is a need for jobs in government. ${ }^{16}$

If there was previously a provision "never hostile to the Indonesian Revolution," then in this law, there is no such provision. Obedience to the state is formulated into the

${ }^{16}$ Article 10 Law Number 18 of 1965 concerning the Principals of Local Government 
requirement "never hostile to the struggle for independence of The Republic of Indonesia."

Furthermore, those who become candidates for the Head of Desapraja must go through the selection process conducted directly by the local community. In general, 18 years old or have/have been married and/or recognized local customs already have the right to vote. Furthermore, the Head of Level II appointed the Head of Desapraja at least two candidates and three candidates. After the Head of Desapraja is elected, he will serve for eight years. The democratic space gives the village and the villagers full rights in choosing and determining the future leader.

This law has not fully set in detail the conduct of the election. There is no finding of arrangements when problems or disputes occur in implementing village head elections in this law. However, this law has a differentiator between other laws and regulations. The differentiator can be traced to the existence of precise arrangements related to village arrangements and the mechanism of filling the village head. In practice, this law cannot be fully implemented, and its existence is revoked by Law No. 6/1969 with the provisions of law no. 19/1965 passed when the legislation that replaces it has come into force.

\section{Election of Village Heads in the New Order Era}

Village arrangements in this period are contained in Law No. 5/1979 on Local Government. This law, at the same time, repealed Law No. 19/1965. In the legislation, that village can be interpreted as "a number of residents who occupy an area as a unit of law including also in it is the unity of the legal community that has a group (organization) of direct power under the camat and has the right to carry out its own household in the bonds of the Republic of Indonesia."

About the mechanism of choosing the village head, it is stated that every local villager can run for village head on the condition that:

1. Believe in God; 
2. Consistent with the pillars of a state ideology (Pancasila) and the 1945 Constitution;

3. Have a good, fair, honest, authoritative, and intelligent nature;

4. Do not interfere directly or not in activities that mingle in the Unitary State of the Republic of Indonesia as the basis of Pancasila and the 1945 Constitution, such as the September 30Th Movement/Communist Party of Indonesia or other groups of banned organizations;

5. The right to vote is not being revoked by the rule of the court that cannot be contested;

6. Not undergoing confinement based on a decision that has absolute power, because the criminal acts decided a maximum of 5 (five) years;

7. Already a resident of the village and has lived in the village for at least the last 2 (two) years are not disconnected, except that the son of the village is outside the village.;

8. Minimum age 25 years old and maximum 60 years old;

9. Have endurance, healthy physical and spiritual;

10. Minimum diploma of First-Level Secondary School or who has the same knowledge/experience. ${ }^{17}$

Regarding the requirements of obedience to the state, it is still maintained in this law. The difference lies in the existence of a nomenclature that expressly mentions one of the evidence of obedience to the state is not involved in the movement known as G30S/PKI or other illicit activities. The inclusion of this provision resulted from the dark history of the PKI, which led to the massacre of high-ranking Indonesian military officers on 30 September 1965.

Furthermore, concerning the selection of village heads conducted through the selection mechanism conducted by the local villagers, prospective voters must be 17 years old and/or have/have been married, as evidenced by a marriage certificate. This arrangement aligns with Law No. 19/1965, which rewards residents in determining their leader through the electoral process. The Regent/Mayor then appoints the elected

${ }^{17}$ Article 4 Law Number 5 of 1979 Concerning National Legal Development Agency 
village head candidate on behalf of the Governor with the provisions of his 8-year term, and the procedure can be reappointed during one year of his/her term.

The same as Law No. 19/1965, in Law No. 5/1979 also does not make arrangements related to the mechanism of supervision and handling of disputes in the implementation of the Village gead elections, including how the control process on the implementation of elections. According to Huda that elections in this period gave birth to much cheating. The fraud occurred in general due to intervention from the power coming from outside the village. The government is involved in winning specific candidates. This condition is very detrimental to the villagers. Because various instruments used by the government must defeat candidates who can fight for their aspirations. On the one hand, there is no space provided in the existing regulations when supervision and resolution of disputes arising from the election outcome.

Not only weak in terms of arrangements related to the selection of village heads. However, this legislation also revokes the spirit of rights, authority (autonomy) in the village. Then put the village as a medium used by the government to control people's lives through the village head. This condition is the same in the colonial era, which is feudalistic. Suharto not only monopolized village life but also state life. This can be seen from the significant influence of Suharto on every line of state life.

\section{Election of Village Heads in the Reform era}

Village-related arrangements in this period, carried out through Law No. 22/1999, Law No. 32/2004, and Law No. 6/2014. The year 1999 was the beginning of the reforms. The reform era made many changes in the constitutional system, including reforming the constitution. The arrangement of the village, which was previously stipulated in its law, in its course is then united in the arrangements related to the local government was enacted in Law No. 22/1999. Consideration of the law's birth is to provide flexibility for regions in Indonesia to organize autonomy in managing their regions. The provision of flexibility to organize regional autonomy is considered necessary to improve democratic principles, society participation, equity, and justice, and supervise capabilities and diversity in regional areas. 
Article 1 letter o Law No. 22/1999 defines the village as "the unity of the legal community that has authority in the regulation and management of the interests of the local people on the basis of origin and customs agreed on the components of national government and located in the district."

This law mandates that the filling of the village head be done through the selection mechanism directly carried out by the villagers. Neither this law nor its derivative rules, namely: Government Regulation No. 76 of 2001, has never qualified the age requirement for residents who exercise their voting rights. However, in practice, the election is conducted by 17 (seventeen) years old and/or who has/have been married.

The conditions that a person must meet in the running for village head are villagers with the following conditions:

1. Believe in God;

2. Consistent with the pillars of a state ideology (Pancasila) and the 1945 Constitution;

3. Do not interfere directly or not in activities that mingle in the Unitary State of the Republic of Indonesia as the basis of Pancasila and the 1945 Constitution, such as the 30 September Movement/Communist Party of Indonesia or other groups of banned organizations;

4. Minimum diploma of First-Level Secondary School or who has the same knowledge/experience.

5. Minimum age 25 years;

6. Have endurance, physical and spiritual health;

7. Has no mental disorder/amnesia;

8. Have a good, fair, honest, authoritative, and intelligent nature;

9. Not undergoing confinement based on a decision that has absolute power, because the criminal acts decided a maximum of 5 (five) years;

10. The right to vote is not being revoked by the rule of the court that cannot be contested;

11. Know the condition of the area and known by the local villagers

12. Ready to be nominated village head candidates; and

13. Meet all other requirements based on customs following the rules in the local government.

The above requirements are not much like the previous Law (Law No. 5 of 1979). The ban on people who had participated in the G30S/PKI movement was still maintained. Suppose the previous law contains the provision that a prospective village head should have been a resident and resided in the village for at least two years. In that case, the 
terms of the prospective village head are sufficient to know the village where he or she is running.

Candidates for village heads who received superior vote support in the BPD were then approved or ratified by the local government, the Regent. Kades served for ten years or 2 (two) terms. Regarding the arrangement of this term of office is subject to a change from the previous law, which states that the office of the Head of Village for eight years can then be re-elected again in one term.

Law No. 22/1999 was replaced by Law No. 32/2004 due to Article 18 of the 1945 Constitution in 2000. The selection of village heads according to Law No. 32/2004 is conducted through a straightforward selection process by the local community, who are 17 (seventeen) years old or have been married.

Law No. 32/2004 delegates the rules on prospective Cadres to government regulations. The requirements to become a Village Head are:

1. Believe in God;

2. Consistent with the pillars of a state ideology (Pancasila) and the 1945 Constitution; and government;

3. Minimum diploma of First-Level Secondary School or who has the same knowledge/experience;

4. Minimum age 25 years old;

5. Ready to be nominated of Village head;

6. Is a local citizen/ resident;

7. Not undergoing confinement based on a decision that has absolute power, because the criminal acts decided a maximum of 5 (five) years;

8. The right to vote is not being revoked by the rule of the court that cannot be contested;

9. Not yet a Kades for a maximum of 10 years or even two terms of office; and 10. Other requirements of local regulations are met. ${ }^{18}$

The requirements of village head candidates and the selection process of village heads, as stated above, no longer give rise to a ban for village head candidates actively involved in the G30S/PKI movement. However, the terms still maintain the provisions on loyalty to the state for each prospective village head. The loss of the prohibition provisions for everyone involved in the 30S/PKI Movement as a form of protection of

${ }^{18}$ Article 44 Government Regulation number 72 of 2005 concerning Village 
everyone in human rights to channel their political rights as guaranteed by the constitution. One of the consistent figures in fighting for this is Abdurahman Wahid (commonly called Wahid). During his reign, Wahid had wanted to remove TAP MPRS No. XXV/MPRS/1966 related to the dissolution of the PKI and the declaration as a banned organization, and a ban on the spread of communism in Indonesia. What Wahid did as a form of "breaking the violence of the past."19 Because after the 30S/PKI Movement, the state through Suharto sentenced approximately 1 million people to support the PKI movement. The sentencing was dismissed without going through the judicial process. Not stopping there, the PKI was identified as a political organization that sought to change the ideology and basis of the state so that their rights need to be restricted. One of the restrictions on this right can be seen from the provision of "not involved in the 30S/PKI Movement" as part of the requirements of kades candidates in Law No. 5/1979, which then continued to be maintained by Law No. 22/1999.

In its development, the provision stating the terms "not involved in the 30S/PKI Movement" slowly began to be eliminated on the basis that everyone had rights, including the right to vote and be elected. By basing this consideration of human rights, the Constitutional Court, through its decision numbered 001-017/PUU-I/2003 nullifying Article 60 letter g of Law No. 12/2003 essentially contains the clause "prospective legislators are not cadres of members of the Communist Party of Indonesia or do not interfere in the G30S / PKI. The cancellation of the provision makes Article 60 letter (g) of Law No. 12/2003 that does not have a binding legal force. In the end, any clause relating to the restriction of rights for those who had been involved in PKI movements, including the G30S/PKI, was no longer a dead price to keep.

Other differences that can be found in Law No. 22/1999 and Law No. 32/2004 are related to the tenure of the village head. If in Law No. 22/1999 that the length of the

${ }^{19}$ Akmaliah, Wahyudi. (2015). "Indonesia Yang Dibayangkan: Peristiwa 1965-1966 dan Kemunculan Eksil Indonesia." Jurnal Masyarakat \& Budaya, 17(1): 65-76. 
position of Kades and time is given for 10 (ten) Years. In-Law No. 32 of 2004, the term of office of the village head is 6 (six) years and can be re-elected for only one term.

Both Law No. 22/1999 and Law No. 32/2004 do not make arrangements related to the supervision of the implementation of Village head election and dispute resolution mechanisms village head election. A new dispute resolution mechanism in PP No. $72 / 2005$ concerning Villages is a regulation on the implementation of Law No. $32 / 2004$. Nevertheless, the dispute resolution mechanism is delegated to the local government to regulate it through local regulations. This means that the government issues no standard guidelines to serve as the basis for local governments to design a pattern of dispute resolution arising from the selection process of village heads. Thus the mechanism of settlement was carried out following the tastes of the local government. It is a "weapon" for the head of the region to pass one of the parties favored by the head of the region even though it is not the community's choice. Likewise, it will be a disaster for candidates who are not affiliated with the regional head.

In 2014 the rules on village arrangements were separated from the rules on local government. So the rules on villages were born (Law No. 6 of 2014) and rules on local government (Law No. 23 of 2014).

Article 31 of Law No. 6/2014 mandates that village head elections be carried out jointly in all districts/cities. Furthermore, related to the mechanism of Pilkades in the provisions contained in this law began to be done rigidly. Furthermore, article 34 paragraph (3), which lists the stages of village head elections, consists of nomination, voting, and determination. The phasing of the implementation of this election is then translated into Article 41 paragraph (1) PP 47/2015 concerning Amendments to PP No. 43/2014 concerning the rules of Implementation of Law No. 6/2014, to 4 (four) stages each: preparation stage, stage, nomination voting stage, and determination stage.

If reading the requirements of prospective Cadres, which is contained in Article 33 of Law No. 6/2014, does not differ much from the requirements in PP No. 72/2005, which 
is a derivative of Law No. 32/2004. If in PP No. 72/2005 one of the conditions as Cakades is native to the local village, then Law No. 6/2014 changed with the prospective village head being a resident and residing in the village for at least one year. The inclusion of the minimum limit as a local villager was later annulled by the Constitutional Court through a ruling numbered 128/PUU-XIII/2015.

Although the process of selecting the village head has been arranged in such a way, the legislator and its derivative regulations are missed in setting the supervisory mechanism and the mechanism of resolving the dispute of the village head election.

First, the surveillance mechanism. Both Law No. 6 of 2014 and its derivative rules do not make arrangements related to the supervision mechanism of the implementation of elections and who should be the supervisor in implementing village head elections. If you look again at Article 38 paragraph (2) of the Regulation of the Minister of Home Affairs No. 112/2014 concerning the Selection of Village Heads mentioned that: "the agenda of the committee as stated in paragraph (1) that can attend i.e. witnesses from the candidates themselves, the Village Consultative Agency, supervisors and the community," In the construction of the article very clearly mentions the existence of supervisors in the implementation of village head elections. Ironically, it is not mentioned who is referred to as the supervisor in the article. Because it is not clear who is referred to as the supervisor in the article, it is challenging to find arrangements related to monitoring the selection of village heads. On the other hand, the Minister of home affairs regulation attached the supervisory duties to the selection committee of the village head at the regional level. However, it did not elaborate on how it was processed.

According to Yuningsih and Subekti20, the selection of village heads can not only be understood as an effort to give birth to the leader of the people's choice. However, it also concerns the pride and honor of the prospective village head. This makes the

\footnotetext{
20 Yuningsih, Neneng Yuni., \& Subekti, Valina Singka. (2016). “Demokrasi Dalam Pemilihan Kepala Desa? Studi Kasus Dengan Tipologi Tradisional, Transisional, dan Modern di Provinsi Jawa Barat Tahun 20082013". Jurnal Politik, 1(2): 231-261.
} 
village head use all means to win this procession, resulting in conflict at the community level.

So inevitably, an institution is required that is given a particular task to carry out supervision in the process of implementation. The supervisor of the village head election can not be attached to the election committee. There will be a monopoly of authority in the implementation of village head elections if the implementation of all stages is dominated only by the committee.

Second, the mechanism of handling village head elections problem. Law No. 6/2014 mandates that the Regent /mayor resolve the dispute kades 30 days at the maximum at the time of receipt of the results of the village head elections. The granting of authority to handle village head elections problems by the Regent/ Mayor makes the role of regional heads very vital. This can cause a conflict of interest because the regional head has political calculations in maintaining his position in the following regional head election. Undeniably, head of village is a central person in the lives of the people in the village. Until the Village head has the expertise to mobilize the community to drop his choice in the regional head election event, in such circumstances, a reciprocal relationship between the regional head and Village head candidates will be decided on the Pilkades dispute where the regional head has the authority to resolve it.

Government Regulation No. 47 of 2015 mandates the subsequent arrangement of implementing village head elections rules through local regulations. One of the expected points to be regulated in the regional regulations is handling village head elections. However, the final decision is on the regional head (see Article 37 paragraph (6) of Law No. 6 of 2014).

The regulatory model related to handling village head elections should not be authorized to decide the dispute. A new mechanism is needed in resolving disputes for the selection of village heads, namely the establishment of particular institutions that are ad hoc. The choice of an ad hoc institution is based on the reason that a permanent dispute resolution institution is, in principle, a judicial institution that has the 
constitutional authority to adjudicate and resolve disputes that are repeated in different cases. In addition, the establishment of a permanent institution will require a large budget and resources. Therefore, this criterion limits the institution of resolving disputes of village heads that are permanent and only ad hoc. However, in supporting the implementation of duties and authorities in resolving any disputes submitted, this institution needs to be equipped with instructions for resolving disputes on the selection of village heads or can be called by the law of handling the issue of Village Head Elections.

The separation of authority for the settlement of disputes village head elections, which was initially in the hands of the regional head to the particular institution as a form of application of the principles of the state of law and democracy that ultimately provides guarantees against the protection of constitutional rights for each candidate of the village head who is contesting.

\section{Conclusion}

The arrangement of the selection of village heads has its dynamics in line with the political dynamics of the state's laws in the country. We can see the legislation at any period. There is a measure of loyalty to the country by stating a clause on "not obstructing the Indonesian Revolution." In its development, the provision was later omitted and replaced with the provision "not involved with pki activities and its mass organizations including not being involved in the 30S/PKI Movement". This requirement was later eliminated, but the conditions related to loyalty to the state were carried out universally, namely "Consistent with the pillars of state ideology (Pancasila) and the 1945 Constitution, the Unitary State of Indonesia and bhineka Tunggal Ika".

All the rules concerning village head elections, both from the beginning of independence to the present, have not made rigid arrangements related to the monitoring mechanism and resolving disputes of village heads. Therefore, changes to the current regulations are needed to improve the quality of the selection results of the village head. 


\section{Acknowledgement}

Our thanks to LPPM UNG for allowing us to do this research. This research is part of the next stage of research, which will design the supervisory mechanism and dispute resolution mechanism of village head election.

\section{References}

Bahar, Syafroedin. et.al (editor). (1995). "Risalah Sidang BPUPKI-PPKI 28 Mei 1945-22 Agustus 1945”. Jakarta: Sekretariat Negara RI.

Hasanul. Bulqiyah., Sholeh, Muadi., \& Sholeh George Towar Ikbal. (2019). "Pemilihan Kepala Desa dan Partisipasi Masyarakat Marjinal: Studi Kasus di Pulau Bawean, Indonesia". Jurnal Wacana Politik, 4(1), 68-80.

Huda, Ni'matul. (2015). “Hukum Pemerintahan Desa Dalam Konstitusi Indonesia Sejak Kemerdekaan Hingga Era Reformasi”. Malang: Setara Press.

Maschab, Mashuri. (2013). "Politik Pemerintahan Desa di Indonesia". Yogyakarta: Polgov.

MD, Mahfud. (2010). "Politik Hukum di Indonesia”. Jakarta: PT. RajaGrafindo Persada

Pinilih. And Gading, Sekar Anggun. (2016). "Laporan Penelitian Perkembangan Pegaturan, Hukum, Pemilihan Kepala di Indonesia”. Semarang: FH Undip.

Syafrudin, Ateng and Na'a. Suprin. (2010). "Republik Desa: Pergulatan Hukum Tradisional dan Hukum Modern Dalam Desain Otonomi Desa”. Bandung: PT. Alumni.

Tome, Abdul Hamid. (2020). "Membumikan Pancasila: Upaya Pelembagaan Nilai Pancasila Dalam Kehidupan Masyarakat Desa”. Jurnal Al-'Adl, 13 (1): 118-131.

Yasin, Muhammad. et. al. (2015). "Anotasi Undang-Undang No. 6 Tahun 2014 tentang Desa". Jakarta: PATTIRO bekerjasama dengan The Asia Foundation.

Yuningsih, Neneng Yuni., \& Subekti, Valina Singka. (2016). "Demokrasi Dalam Pemilihan Kepala Desa? Studi Kasus Dengan Tipologi Tradisional, Transisional, dan Modern di Provinsi Jawa Barat Tahun 2008-2013". Jurnal Politik, 1(2): 231-261.

Wahyudi, Akmaliah. (2015). "Indonesia Yang Dibayangkan: Peristiwa 1965-1966 dan Kemunculan Eksil Indonesia." Jurnal Masyarakat \& Budaya, 17(1): 65-76.

\section{Laws}

Government Regulation number 72 of 2005 concerning Village

Law Number 18 of 1965 concerning the Principals of Local Government Law Number 5 of 1979 Concerning National Legal Development Agency 